\title{
New Requirements of Teachers' Abilities in Case Teaching
}

\author{
Hu Yamin ${ }^{1}$ \\ ${ }^{1}$ Air Force Early Warning Academy, Wuhan 430019, \\ China \\ Lv Shujun ${ }^{1}$ \\ ${ }^{1}$ Air Force Early Warning Academy, Wuhan 430019, \\ China
}

\begin{abstract}
As the leader of the case teaching, teachers play an important role in the successful implementation of case teaching. In this paper, we propose three-roles of teachers including gatekeepers, guides and the presenters through analyzing some key problems in the process of implementing case teaching. And we also put forward new teaching ideas and new case requirements, etc.
\end{abstract}

Keywords: case teaching; role; requirement.

\section{INTRODUCTION}

Different from traditional teaching, case teaching has its own special principles and methods including teaching contents, teaching forms, teaching skills and blackboard writing ways, teaching plan etc. If teachers don't grasp the basic ideas of case teaching, it must be a bad case teaching. Therefore, teachers in case teaching must be familiar with the basic teaching theory knowledge, solid foundation for teaching.

\subsection{Being familiar with basic teaching theoretical knowledge is the foundation of the tissue case teaching}

Most of case teaching is given priority with discussion while students have more right of dominions. To guarantee the effect of case teaching, we must carefully design the teaching process. One is the analysis of case study. Case is selected, teachers must have a a comprehensive analysis and control of the selected case, familiar with its background, facts, views, outstanding knowledge, master the heavy difficulty of case, determine the case contain the principles and rules, clearly train students' abilities, and predict their results [3]. Second, through the analysis center, setting the reasonable questions, guaranteeing the time division of case discussion, teachers need write out the detailed teaching plans.

\author{
Hu Yahui ${ }^{1}$ \\ ${ }^{1}$ Air Force Early Warning Academy, Wuhan 430019, \\ China \\ Fang Qiqing ${ }^{1}$ \\ ${ }^{1}$ Air Force Early Warning Academy, Wuhan 430019, \\ China
}

1.2. Grasping students' behaviors is the key to the organization case teaching

Teachers should accurately grasp the students' behavior including their irrational factors, mood and emotional reflections, and also should have a better prediction to avoid some unexpected circumstances. To determine whether students can understand the content of the case described or not can give enough attention to the basic problem with their knowledge to case analysis [4].

\section{Three roles of teachers}

\subsection{Selecting good cases to be a good gatekeeper}

It is the key of successful implementation in case teaching to select some targeted, practical, typical and scientific cases. First, according to the teaching objects, teaching contents and teaching target to select cases. Then, case selection should be realistic and practical. Cases only can reflect the reality to resonate with students thoughts, trigger their interest in learning. It is necessary to summary their experiences and lessons. And according to the teaching contents and students' actual levels, the selected cases must be typical. closely linked with the actual demands, moderate difficulties and even representative.

\subsection{Guiding students' discussion closely to be a good guide}

During the discussion, students are the center part of the case. And teachers not only inspire students' thoughts, arouse their enthusiasm participating in discussions, but also guide them around case center issues actively. Importantly, the methods of guiding must be reasonable to avoid the deviation from discussing the teaching purpose.

\subsection{Summarizing comments to be a good presenter}

Summarizing comments is an important part of case teaching, which contains discussion opinions, discussion results, discussion evaluation, etc. Reveal the basic theory 
behind problems will help their understanding of case teaching to enlighten and improve their abilities and potentials.

\section{New requirements of teachers}

\subsection{Updating teaching ideas}

It is the base of the actual, interactive and wide open case teaching to update teachers' teaching ideas. In the implementation of case teaching, teachers not only should have the preparation and organization of case teaching abilities, but also have rich theoretical knowledge and high academic standards, penetration and integration of theory and practice ability to keep the forefront of research in the latest trends. Sometimes, teachers should also have strong ability of strain and judgment, can timely analysis and solve the new problem and conclude to be objective and scientific evaluation and guidance [2].

\subsection{Teachers should attach importance to case, edited and class design}

Before teaching, first of all, teachers must have a strict teaching plan, a clear scope of cases, and a scientific and reasonable arrangement of teaching content. Second, teachers should carefully select and compile good cases on the basis of field investigation of students [5]. Especially those closely related to students' lives cases are the first choices. According to the materials be form the course design, teachers must be very familiar with the case such as background, facts, views, etc.

\subsection{Teachers should be the correct position to guide the case discussion process}

In traditional teaching, teachers' roles are teacher men or interpreters, whose duties are familiar with teaching materials, lesson plans, clear logic structures, etc. But case teaching is a special way of teaching activities different from traditional teaching method [2]. In case teaching, teachers are the guiders while students are the center of teaching, which have a role conversion and relocation process.

\section{Conclusions}

It is important for case teaching to understand the three-roles of teachers including selecting good cases to be a good gatekeeper, guiding students' discussion closely to be a good guide, and summarizing comments to be a good presenter. And we will do our best to improve our teaching level in the case teaching.

\section{Acknowledgments}

Sponsored by Fellowship for: 2013ZDJC0101

\section{References}

[1] Li Ying. Case teaching under the background of teachers role conversion technology. Culture education, 2011 (10)

[2] Duan Huijuan, et al. Some problems of case teaching. Market weekly, 2007 (1)

[3] Li Yunqing. The main problems of case teaching and countermeasures. Journal of chongqing institute of technology, 2011 (1)

[4] Kang Qinchun. The change of teachers' roles in case teaching. Journal of Huzhou Teachers College, 2008 (6)

[5] Liu Yuqin. Secondary vocational school thinking about the problems of case teaching. vocational education form, 2008(6).

[6] Zhang $\mathrm{Li}$, et al. Improve the case teaching of management thinking. Journal of huaibei vocational and technical college, 2009 (2) 